\title{
Archaeoastronomical analysis of the Roman Colonia Marciana Ulpia Traiana Thamugadi (Timgad), founded at the sunrise of Trajan's Birthday
}

\author{
Amelia Carolina Sparavigna \\ Politecnico di Torino
}

\author{
Written 2 February 2019. DOI: 10.5281/zenodo.2555783 \\ Revised 1 May 2019. DOI: 10.5281/zenodo.2656658
}

It was told that the Roman Colonia Marciana Ulpia Traiana Thamugadi (Timgad in Algeria), founded in $100 \mathrm{AD}$, had been oriented to the sunrise on the day of Trajan's birthday, given as September 18. This Gregorian date corresponds to September 17 of the Julian Calendar. Here we use software such as CalSKY and Stellarium to investigate the sunrise azimuth and compare it to the direction of the decumanus of the Roman town. After the archaeoastronomical analysis we can conclude that the assertion concerning the orientation of Timgad to the sunrise of the day of

Trajan's birthday could be true.

In 2012, I wrote an article concerning the orientation of Trajan's town of Timgad [1]. Timgad was a Roman colonial town founded by the Emperor Trajan in AD 100. The Roman full name was "Colonia Marciana Ulpia Traiana Thamugadi": in this name we find the names of emperor's mother Marcia, his father Marcus Ulpius Traianus and his eldest sister Ulpia Marciana. The ruins of the Trajan's Timgad are in Algeria. In the book entitled "Ancient Town-Planning", written by F. Haverfield and published in 1913 [2], Timgad is proposed as a noteworthy site for being one of the best examples of the Roman city planning. When the author wrote the book, about Trajan's Timgad there were only purely archaeological remains. Haverfield reported that the ruins are on "the northern skirts of Mount Aurès, halfway between Constantine and Biskra and about a hundred miles from the Mediterranean coast. Here the emperor Trajan founded in A.D. 100 a 'colonia' on ground then wholly uninhabited, and peopled it with time-expired soldiers from the Third Legion which garrisoned the neighbouring fortress of Lambaesis ... The 'colonia' of Trajan appears to have been some 29 or 30 acres in extent within the walls and almost square in outline (360 x 390 yds.). It was entered by four principal gates, three of which can still be traced clearly, and which stood in the middle of their respective sides; the position of the south gate is doubtful. According to Dr. Barthel, the street [decumanus] which joins the east and west gates was laid out to point to the sunrise of September 18, the birthday of Trajan." [2,3].

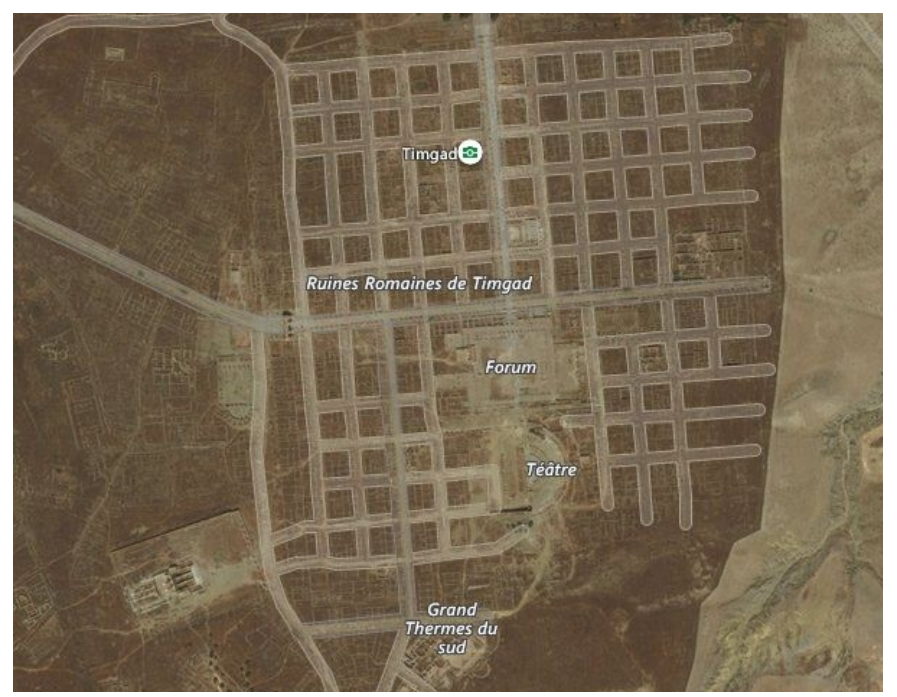

Figure 1: Timgad seen from space with streets evidenced (Courtesy: Bing Maps). 
From the Figure 1, it is clear the reason for proposing in [2] this town as an example of the layout of Roman colonies. As told in [3], it seems that the Roman colonies were founded according to an ancient ritual. An augur (a religious official), after inspecting good omens from skies, decided the place of the future town and the orientation of the main street, the Decumanus Maximus. Then the intersecting axis of the Cardo was given as perpendicular to the Decumanus. After the augur's decision, surveyors were deputed to transfer the plan devised by the augur on the land, by means of a surveying method which is known as "centuriation". This is the same method that the Romans used to subdivide the land for agriculture. If the assertion that we find in [2] is true, it means that Timgad has the decumanus oriented to the sunrise on September 18. So let us start our analysis.

\section{Using CalSKY}

In [1] I used an approach based on satellite images and on a rather simple equation, to discuss what Haverfield is telling about Timgad [2]. Instead of using the equation given in [1], we can use software CalSKY. Actually, detailed discussion and tables are given in [4], so we do not repeat them here. Summarising: let us consider the day of 18 September of 2019 and 100 AD at Timgad. We have that sunrise azimuth on September 18 (without considering the local natural horizon and the effect of the atmospheric refraction), it was of $86.4^{\circ}$ in $100 \mathrm{AD}$; it is of $87.0^{\circ}$ in 2019 . The altitude of the sun is $56.4^{\circ}$ in 2019 ; it was $56.9^{\circ}$ in 100 AD. So, a difference of half a degree exists for the altitude of the sun due to the fact that the tilt of the Earth's axis slightly changed in two thousand years.

Let us consider the azimuth $86.4^{\circ}$ and compare to the direction of the decumanus. Here we use satellite images. From a Bing Map we have the following Screenshot 1.

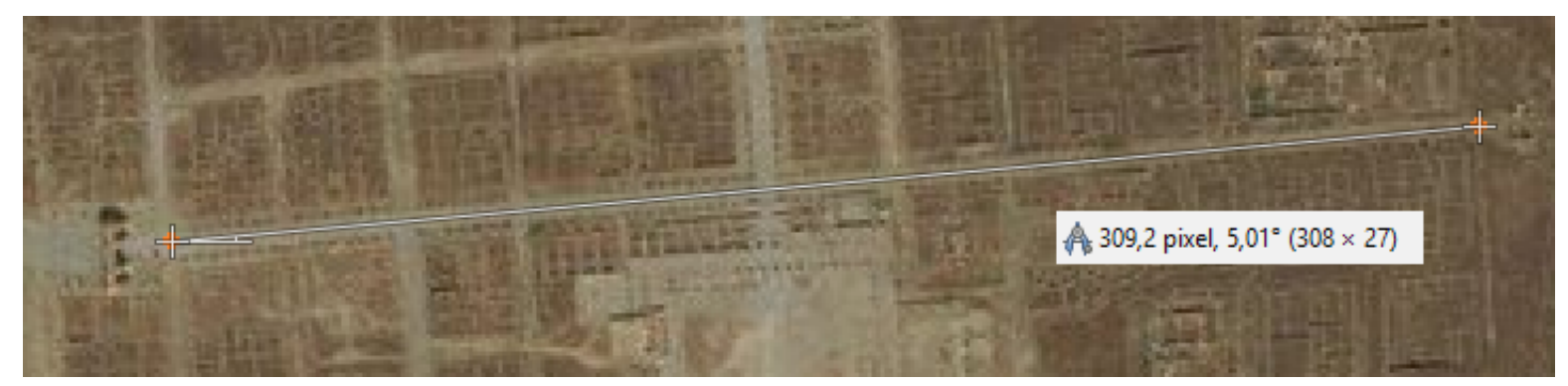

Screenshot 1: Satellite image courtesy Bing Maps. The azimuth of the decumanus is of about $85^{\circ}$.

In the screenshot you can see the measurement of the angle made by means of GIMP pair of compasses. The azimuth of the decumanus, from true North, is of about $85^{\circ}$. As a conclusion, using CalSKY, we have that it is possible that Timgad had been founded on 18 September $100 \mathrm{AD}$, if we consider that a difference of about $1.5^{\circ}$ can be due to the used surveying method and the fact that the atmospheric refraction had been not considered.

Actually it is possible to reduce the difference including the effect of atmospheric refraction. Let us assume, roughly, that the atmospheric refraction could affect the azimuth of $0.5^{\circ}$, then the sunrise azimuth could be estimated as $86^{\circ}$, and the difference reduces to a degree. This is a result which is far better than that given in [1]. The result proposed in [4] is given for an astronomical horizon.

\section{The natural horizon}

Of course, it would be better to have a local survey. But, in the case that this is not possible, we can use Google Earth, to investigate the horizon. We can use a long straight line, along the Timgad decumanus, in the direction of the sunrise. Google Earth provides the elevation profile along this line (see the Figure 1). 


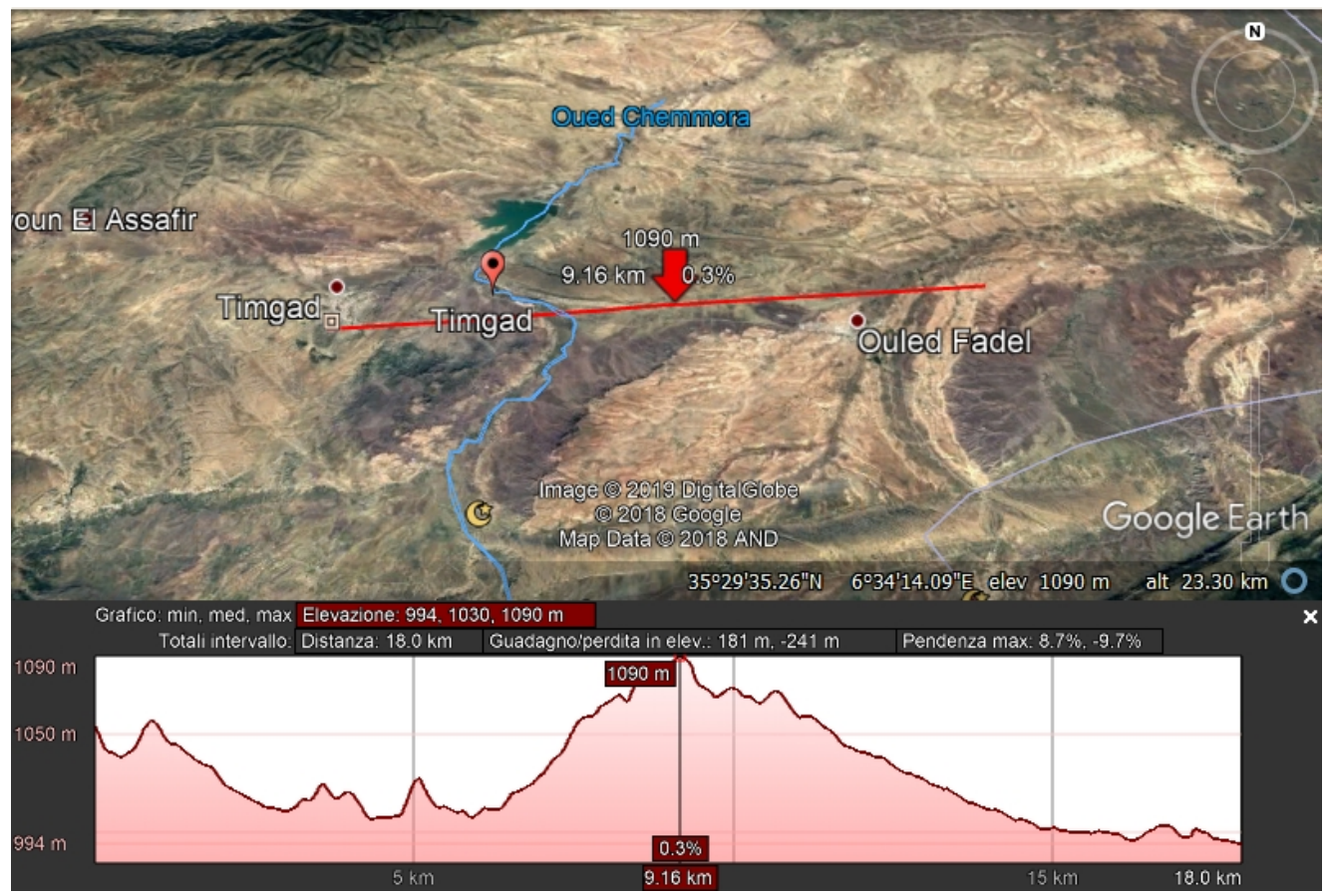

Figure 1: The elevation profile is a courtesy of Google Earth. Using the peak marked in the figure, we find that the natural horizon is $0.21^{\circ}$ (that is $13^{\prime}$, in the further analysis we will round it to 15') above the astronomical horizon.

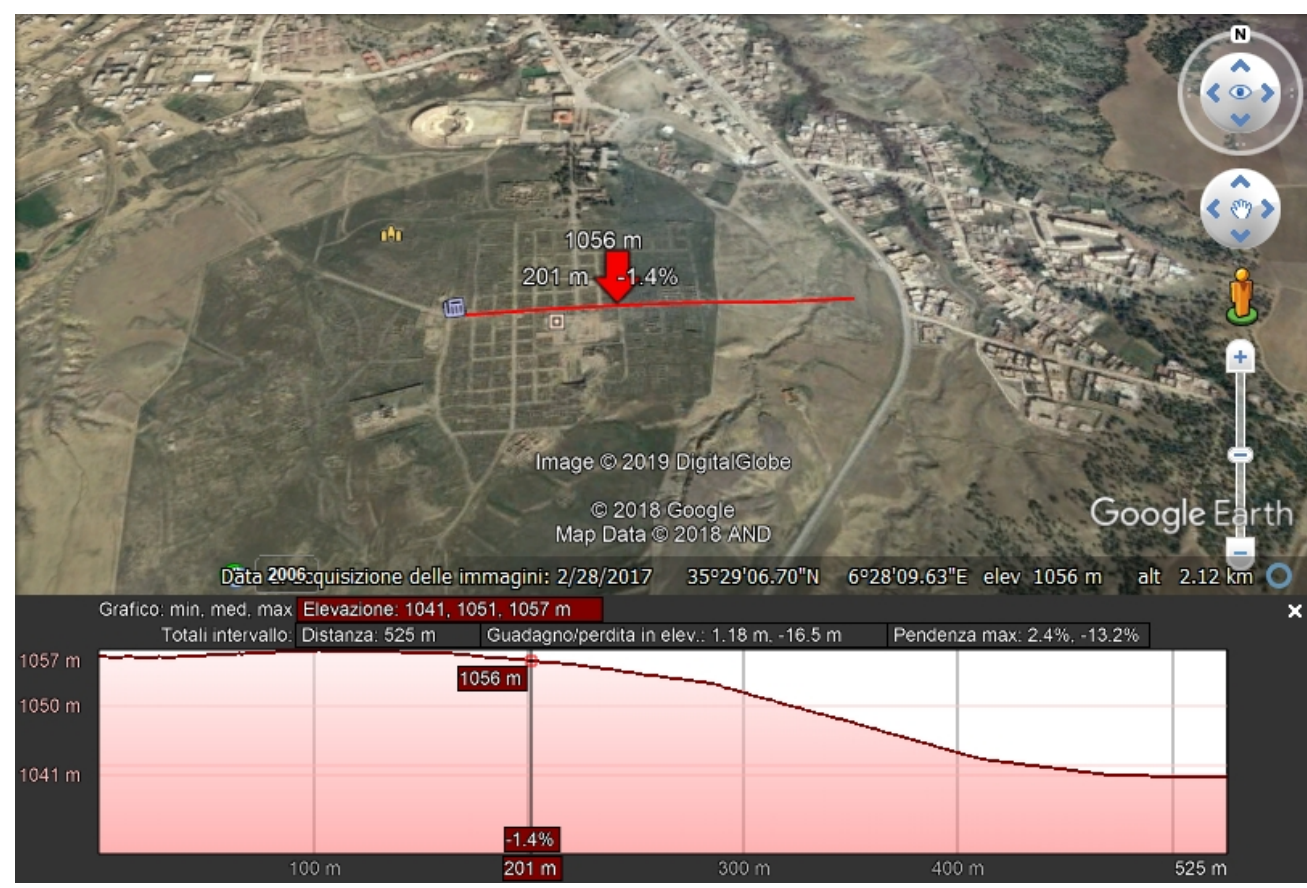

Figure 2: Detail of the elevation profile of the decumanus. Actually, the town is not flat.

Using the peak marked in the Figure 1, we find that the natural horizon is $0.21^{\circ}$ (that is $13^{\prime}$, in the further analysis we will round it to 15') above the astronomical horizon.

Let us consider the profile of the decumanus too. In the Figure 2 we see that the town is not flat. So let us examine two parts of it. First, we consider the part of the decumanus close to the West Gate. Again, Google Earth can help us to find the azimuth of this part of the street. 


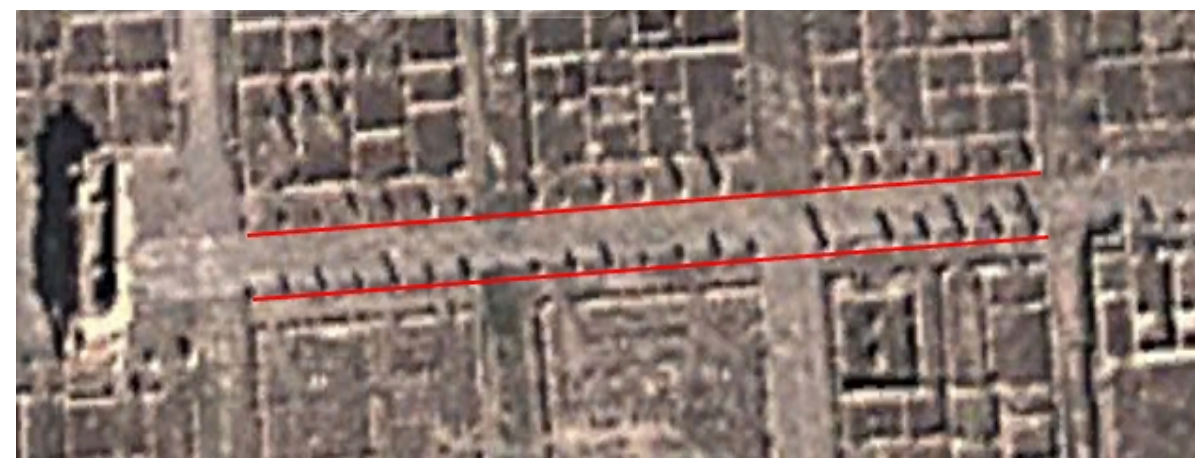

Figure 3. For the measurement of the direction of the decumanus we use the colonnades.

In the Figure 3 we can see the results that we can obtain by means of Google Earth, using its tool for the measurements of lengths and angles. The street is quite broad. Let us consider two red lines corresponding to the colonnades. Azimuth is of $85.57^{\circ}$ for the upper red line and $85.65^{\circ}$ for the lower red line. Azimuths are given from true North. We assume the value of $85.60^{\circ}$, within plus/minus $0.10^{\circ}$. Actually, we follow the columns to determine the direction of the street, within this approximation. We can observe them quite well in Google Earth.

If we consider the part of the decumanus near the East gate, we can see that we have a different angle. The result is given in the Figure 4. In the figure we see that the direction is of $86^{\circ}$. This is a very interesting result, because it is, within half a degree, close to the sunrise azimuth of 18 September $100 \mathrm{AD}$ given by means of the analysis made through the use of CalSKY.

Actually, this analysis shows an important fact, that we have not to consider the decumani of the Roman towns as a perfect straight line. The decumanus was an engineered line, planned to give the best result according to the local environment. Of course, better results can be obtained by means of a local survey.

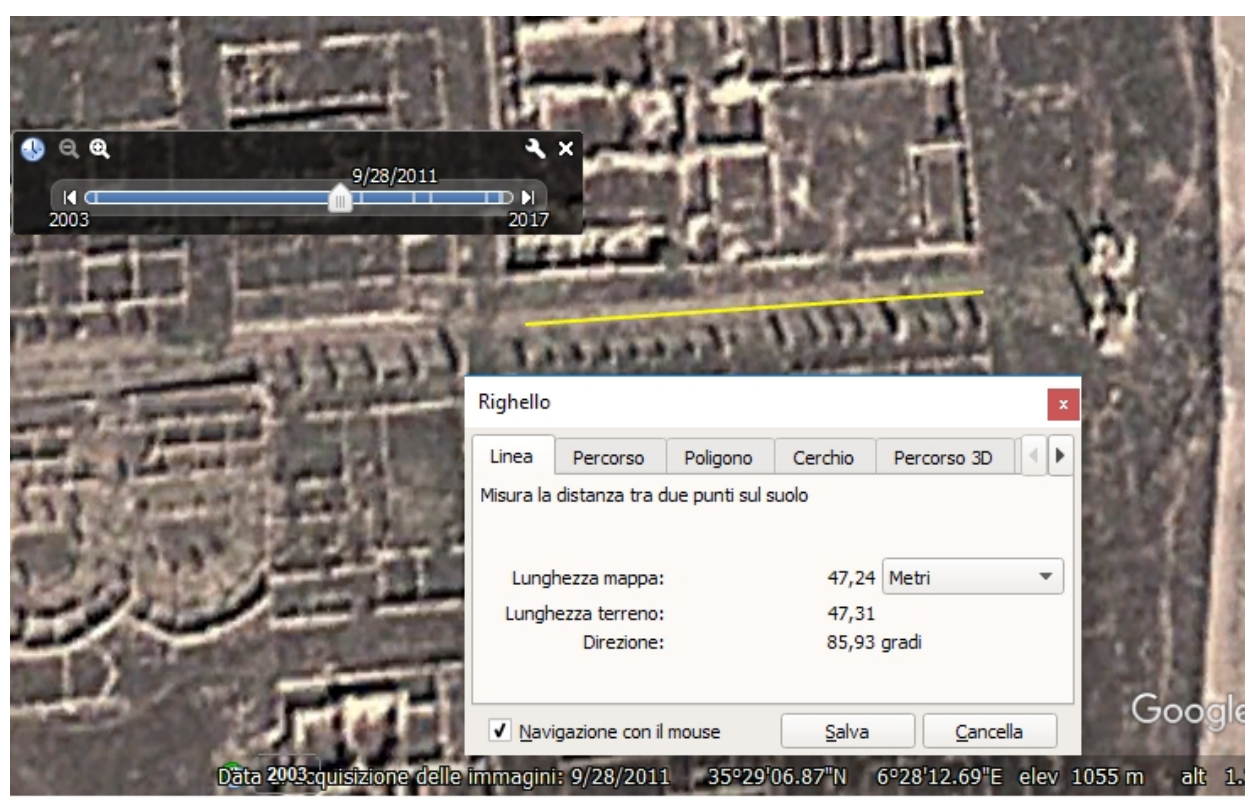

Figure 4.

Let us consider the imagery of Google Earth (28 February 2017), that we have used for the Figures 3 and 4. Let us divide the decumanus in four parts, from the west gate to the east gate. The result is given in the Figure 5. The corresponding directions are given in degrees from the true North, measured using the tool of Google Earth. 

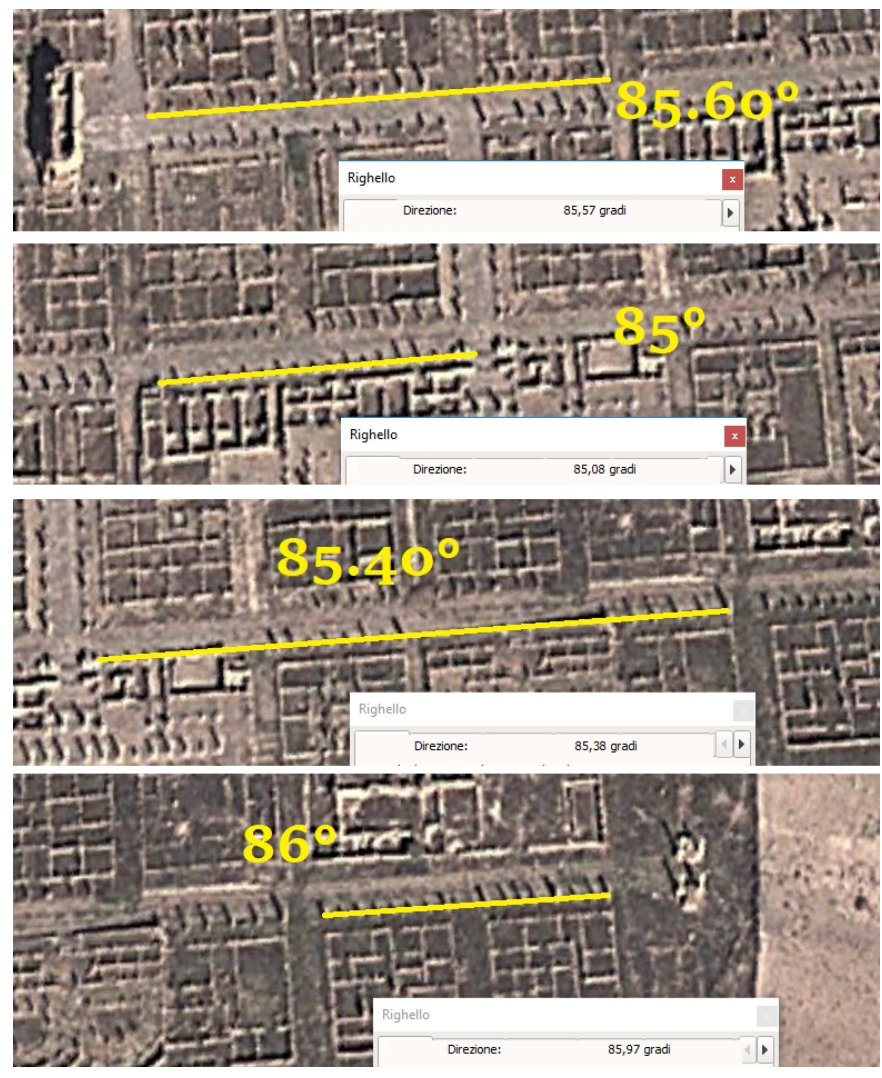

Figure 5. The decumanus is divided in four pieces.

We have the possibility to obtain a mean value of the direction of the decumanus in the following manner. We can average, considering the length of the insulae, calculating: $\left(85.60^{\circ} \times 3+85^{\circ} \times 2+85.40^{\circ} \times 4+86^{\circ} \times 2\right) /(3+2+4+2)=85.49^{\circ}=85^{\circ} 29^{\prime}$. Let us assume this as the direction of Timgad decumanus. We need to give also an uncertainty of this direction. We can choose half a degree, according to the Figure 5: $\left(86^{\circ}-85^{\circ}\right) / 2$. Therefore, the direction of the decumanus is $85^{\circ} 30^{\prime}$ plus/minus $30^{\prime}$.

\section{Using Stellarium}

CalSKY gives us very good results concerning the astronomical horizon, that is the line which is the intersection of a horizontal plane and the vault of the sky. But, as we have seen from the Figure 1 , the natural horizon cannot be assumed as flat. Therefore the sun must be about $15^{\prime}$ above the astronomical horizon to be seen from Timgad. Moreover, we have to consider the role of the atmospheric refraction too. Let us assume an effect of 35': we can reduce the sun altitude to -20'. Furthermore, we could imagine that the augur, or the surveyor, could had observed the first ray of the sun at the sunrise. So we can further reduce of 16', that is half the angular diameter of the sun.

We obtain an altitude of the sun of -36' (the sun is below the astronomical horizon but is can be seen due to atmospheric refraction).

Let us use this altitude in software Stellarium. Please note that Stellarium automatically uses the Julian date for events which happened before the introduction of the Gregorian Calendar [5]. If we use Stellarium at coordinates $35^{\circ} 29^{\prime} 6.51^{\prime}$ ' $\mathrm{N}, 6^{\circ} 28^{\prime} 7.60^{\prime}$ ' $\mathrm{E}$, that is at the coordinates of the place where the Decumanus is crossed by the Cardo, 1058 meters. At Timgad, on September 18, 100 AD, we find, in the conditions given above, that the azimuth was of $86^{\circ} 33^{\prime}$. However, a Julian date of 18 September corresponds to the Gregorian date of 19 September (this is what we find if the use the conversion of the calendars as given by https:/www.galileo.fr.it/marc/varie/calendario/indice.htm). Is Haverfield in [2] giving a Julian or a Gregorian date? We have to investigate. We know that the 
birthday of Trajan is mentioned in a letter written by Pliny the Younger.

Pliny the Younger (A.D. 62?-c.A.D. 113). Letters. The Harvard Classics. 1909-14. Here the Letter XVI to the Emperor Trajan (Courtesy: https://www.bartleby.com/9/4/2016.html).

"AS I had a very favourable voyage to Ephesus, so in travelling by post-chaise from thence I was extremely troubled by the heats, and also by some slight feverish attacks, which kept me some time at Pergamus. From there, Sir, I got on board a coasting vessel, but, being again detained by contrary winds, did not arrive at Bithynia so soon as I had hoped. However, I have no reason to complain of this delay, since (which indeed was the most auspicious circumstance that could attend me) I reached the province in time to celebrate your birthday. I am at present engaged in examining the finances of the Prusenses, their expenses, revenues, and credits; and the farther I proceed in this work, the more I am convinced of the necessity of my enquiry. Several large sums of money are owing to the city from private persons, which they neglect to pay upon various pretences; as, on the other hand, I find the public funds are, in some instances, very unwarrantably applied. This, Sir, I write to you immediately on my arrival. I entered this province on the 17th of September, and found in it that obedience and loyalty towards yourself which you justly merit from all mankind. You will consider, Sir, whether it would not be proper to send a surveyor here; for I am inclined to think much might be deducted from what is charged by those who have the conduct of the public works if a faithful admeasurement were to be taken: at least I am of that opinion from what I have already seen of the accounts of this city, which I am now going into as fully as is possible."

In Latin and in Italian from Le lettere di Caio Plinio Cecilio Secondo, Recate in Italiano da Giuseppe Bandini, Volume 3, Rossetti, 1833.

Sicut saluberrimam navigationem, Domine, usque Ephesum expertus, ita inde, postquam vehiculis iter facere coepi, gravissimis aestibus atque etiam febriculis vexatus, Pergami substiti. Rursum, quum transissem in orarias naviculas, contrariis ventis retentus, aliquanto tardius, quam speraveram, id est XV Calend. Octobres, Bithyniam intravi. Non possum tamen de mora queri, cum mihi contigerit, quod erat auspicatissimum, natalem tuum in provincia celebrare. Nunc rei publicae Prusensium impendia, reditus, debitores excutio; quod ex ipso tractatu magis ac magis necessarium intellego. Multae enim pecuniae variis ex causis a privatis detinentur; praeterea quaedam minime legitimis sumptibus erogantur. Haec tibi, domine, in ipso ingressu meo scripsi. Quinto decimo Calend. Octobres, Domine, provinciam intravi, quam in eo obsequio, in ea erga te fide, quam de genere humano mereris, inveni. Dispice, Domine, an necessarium putes mittere huc mensorem. Videntur enim non mediocres pecuniae posse revocari a curatoribus operum, si mensurae fideliter agantur. Ita certe prospicio ex ratione Prusensium, quam cum Maximo tracto.

Come felicissima ho avuta la navigazione, o Signore, fino ad Efeso, così dal gran caldo, ed anche da febbriciattole travagliato dacchè mi posi a viaggiare per vettura, ho fatto sosta a Pergamo. Messomi quindi di bel nuovo in mare, ma da contrarii venti impacciato, sono entrato in Bitinia alquanto più tardi ch' io nol mi sperassi, cioè a diciassette di Settembre. Non posso però dolermi di troppa tardanza, poiché $\mathrm{m}$ ' è tocco, cosa di lietissimo augurio, di festeggiare in provincia il tuo natale. Ora son dietro a verificare le spese, le rendite, i debitori del comune di Prusa: il che trovo tanto più necessario, quanto più mi profondo nell'esame. Imperciocchè molto danaro sta in mano di particolari per varie cause; altro ancora n' è impiegato in ispese nullamente legittime. Questo a te io scriveva, o Signore, appena entrato nella provincia. Vi son giunto il diciassette di Settembre, ed holla trovata animata di quella divozione e fedeltà, che dal genere umano a te sono dovute. Pensa, Signore, se fia mestieri spedir qua un capomastro: perchè mi sembra che somme non indifferenti potrebbon ripetersi da soprastanti alle opere, se queste fossero esattamente misurate. Di ciò mi persuadono i conti de Prusesi ch' io esamino insiem con Massimo.

From this letter we see that it was September 17 of Julian Calendar. Trajan was born in the year 53 AD. So let us repeat the analysis by means of Stellarium using 17 September. Here the result in Screenshot 2. 


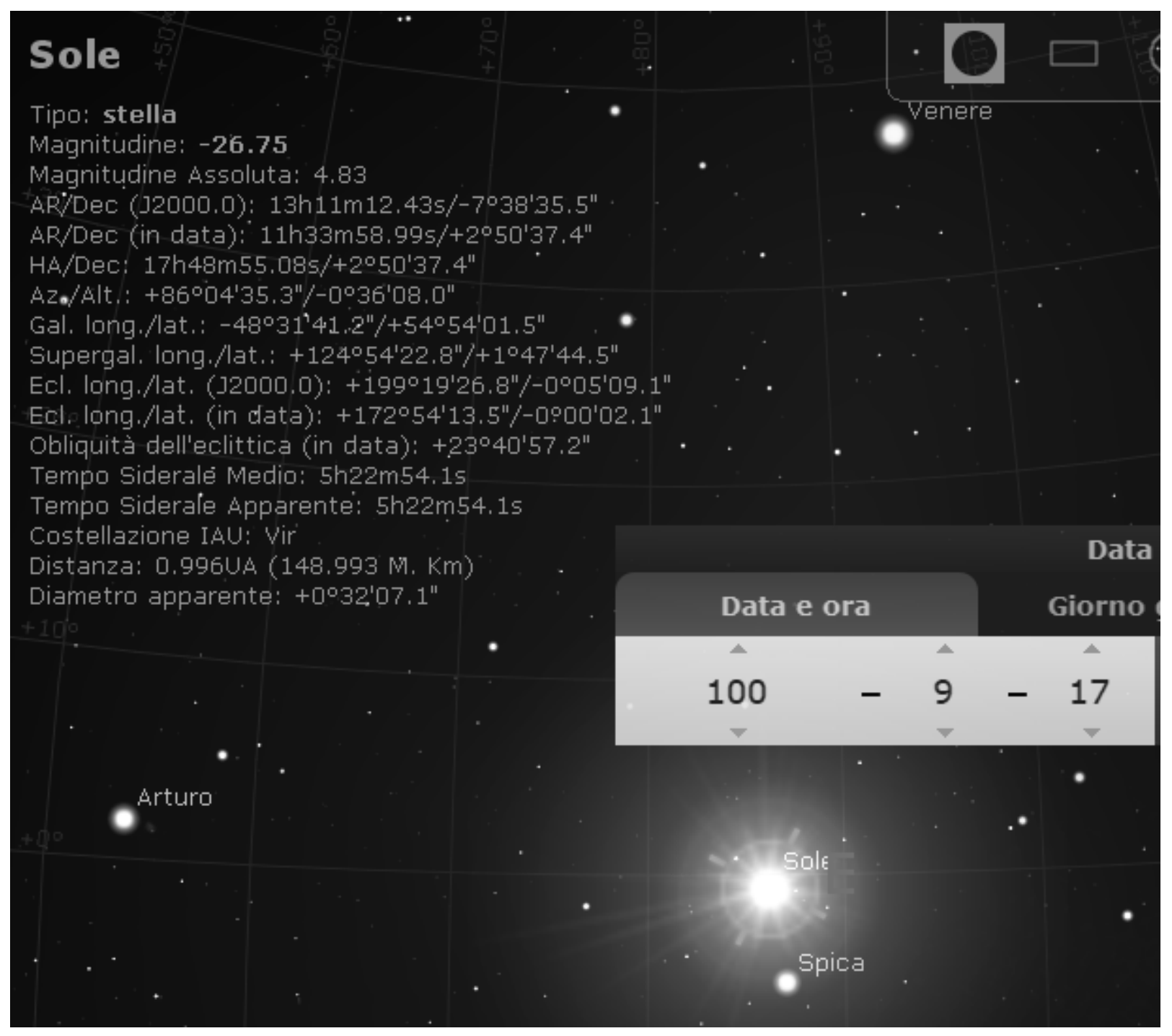

Screenshot 2: Stellarium result.

We find that the sunrise azimuth, according to the previously given conditions, on September 17, $100 \mathrm{AD}$, was of $86^{\circ} 04^{\prime}$. Then, the difference between the average direction of the Timgad decumanus and the sunrise azimuth on 17 September 100 AD was of 34'.

As we have seen, the decumanus of Timgad is not a straight line. Its eastern part had a direction of $86^{\circ}$ (as we can observe from satellite images). As a consequence, the sunrise on September 17, 100 $\mathrm{AD}$, could had been a quite remarkable astronomical show, framed by the East Gate of the town built in the name of Trajan.

However, we have in average a difference of 34'. This fact needs a further investigation. Let us fix the altitude of the sun as -36', and the date, September 17, and using Stellarium, let us investigate the years from $95 \mathrm{AD}$ to $102 \mathrm{AD}$.

We find the following:

$\begin{array}{lllllllll}95 & 96 & 97 & 98 & 99 & 100 & 101 & 102 & \text { years } \\ 85^{\circ} 41^{\prime} & 86^{\circ} 04^{\prime} & 85^{\circ} 56^{\prime} & 85^{\circ} 49^{\prime} & 85^{\circ} 42^{\prime} & 86^{\circ} 04^{\prime} & 85^{\circ} 57^{\prime} & 85^{\circ} 50 & \text { azimuth }\end{array}$

We see that the sunrise azimuth is oscillating of about 20', around a mean value of $85^{\circ} 53^{\prime}$. The direction of the decumanus is $85^{\circ} 30^{\prime}$ as given from Fig.5. If we consider an uncertainty of 30', we have for the decumanus' direction a range from $85^{\circ}$ to $86^{\circ}$. The mean value, that is $85^{\circ} 53^{\prime}$, of the sunrise azimuth is within this given range. As a conclusion, we can tell that, assuming an 
uncertainty of half a degree, and considering the mean value of the sunrise azimuth, it is possible that the decumanus was oriented along the direction of the sunrise on September 17.

We can also observe that, among the years used above, 96 and $100 \mathrm{AD}$ were leap years of the Julian Calendar (as told in Wikipedia, en.wikipedia.org/wiki/Julian_calendar, "after AD 4 the calendar was operated as Caesar intended, so that the next leap year was AD 8 and then leap years followed every fourth year thereafter"). For the leap years, the easternmost part of the Decumanus was fitting the sunrise azimuth within 4'. The azimuth of the years, which were not leap years, are, within half a degree in agreement to the average direction of the decumanus. So it seems that, in planning the town, the surveyors had considered the fact that the point of the horizon, where the sun was rising on the day of Trajan's birthday was changing a little during a period of four years.

\section{Discussion}

Of course, what we have previously told is true in the case that the satellite images are rendering the proper directions of the parts of the decumanus. In any case, as we have seen using Google Earth, it seems that the decumanus was designed to adjust itself on the local surface of the ground. So let us assume its azimuth given as $85^{\circ} 30^{\prime}$. As previously told, the decumanus' direction and the mean value of the azimuth of the sunrise on September 17 are in agreement, within half a degree. That is, assuming an uncertainty of half a degree, the decumanus was oriented along the direction of the sunrise on the day of Trajan's birthday. For what concerns the leap years, as we have told above, the part of the street close to the east gate was perfectly aligned along the sunrise, as it happened for the year of the foundation of the town.

In this framework, we can conclude that the town of Timgad could had been oriented to the sunrise of the day of Trajan's birthday.

Let me add a further observation concerning the year of the foundation of the Roman colonies, in general. It seems to me that it is impossible to determine the specific year of the foundation by comparing the azimuth of the decumanus to the sunrise azimuth. In the case of Timgad, we know the year of foundation, but, in the case it is unknown, we have no means of taking a specific year from those given above, for instance. We can see from the related values and uncertainties, we cannot decide to choose a year as better than the others (perhaps, it is possible to distinguish the leap years). This is due to the fact, and this is clearly shown by the CalSKY results, that the sunrise mean value of a given day of the year, changes of half a degree on two thousand years. Therefore, we cannot determine the year of foundation from any comparison of decumani and sunrise azimuths.

\section{References}

[1] Sparavigna, A. C. (2012). The orientation of Trajan's town of Timgad. arXiv preprint arXiv:1208.0454.

[2] Haverfield, F. (1913). Ancient town - planning, Oxford, The Clarendon Press, 1913, available at http://www.gutenberg.org/files/14189/14189-h/14189-h.htm

[3] Barthel, W. (1911). Römische Limitation in der Provinz Africa, 1911, CXX, pp. 39-

126. Carl Georgi Verlag, Bonn

[4] Sparavigna, A. C. (2019, February 1). The Roman Colonia Marciana Ulpia Traiana Thamugadi (Timgad) and Trajan's Birthday. Zenodo. http://doi.org/10.5281/zenodo.2555082

[5] Sparavigna, A. C: (2017). Stellarium software and the occultation of Aldebaran observed by

Copernicus. Philica, Philica, 2017, 2017 (923). <hal-01435500> 